\title{
Peace Agreements between State and Non-State Parties and International Arbitration: Lessons Learned from the Abyei Arbitration
}

\author{
By Cindy Daase, Leipzig*
}

\begin{abstract}
A Sudanese proverb says that Abyei is the 'eye' of the Sudans. The Ngok Dinka, a pastoralist tribe loyal to the Sudan People's Liberation Movement/Army (SPLM/A), settles in the Area. The Misseriya, Arab nomads with close ties to the Government of Sudan (GoS), drive their cattle through this land. That the Abyei Area turned out to be rich with oil further intensified the dispute between the central government and the secessionist movement in the south.

To address this complex conflict the Comprehensive Peace Agreement (CPA) of 2005 and its Additional Protocols established the Abyei Boundaries Commission (ABC). Based on scientific research and evidence, this group of experts was meant to delimit the Area to enable its demarcation and, in the end, a referendum about its status. The GoS, however, did not accept the ABC's Report arguing that it had exceeded its mandate.

Facing the failure of the entire peace process and a back step into war, the GoS and the SPLM/A submitted an arbitration agreement with the Permanent Court for Arbitration (PCA). In a unique fast track procedure, an international arbitral tribunal had to determine in accordance with the CPA, the Abyei Protocol and Abyei Appendix, the Interim National Constitution and general principles of law, whether the ABC had exceeded its mandate. In case of excess, the parties entrusted the Tribunal of international lawyers with redefining the boundaries of the disputed territory based on their submissions.
\end{abstract}

* Cindy Daase, is a Research Associate at the Leipzig Centre for the History and Culture of East Central Europe (GWZO) and a Ph.D. candidate at the Faculty of Law, FU Berlin (contact: cdaase@zedat.fuberlin.de). This article was presented as a paper at the $37^{\text {th }}$ annual meeting of the "Arbeitskreis für Überseeische Verfassungsvergleichung" in Limburg/Lahn from 5-7 July 2012. The author wants to thank the participants for their comments and a fruitful discussion. This article is also based on the author's research for her Ph.D. thesis on “The Internationalisation of Peace Agreements between State and Non-State Parties" as well as for two previous pieces, Cindy Daase, International Arbitration: A New Mechanism to Settle Intra-State Territorial Disputes between States and Secessionist Movements?, The Divorce of Sudan and South Sudan and the Abyei Question, Osgoode Hall Law School, Comparative Research in Law \& Political Economy (CLPE) Research Paper Series 7 (2011), available at: http://www.ssrn.com/link/CLPE.html (last visited 22 March 2013); and Cindy Daase, The Abyei Dispute between Sudan and South Sudan, The Role of Arbitration in Peace and Secession Processes, in: Thilo Marauhn / Hatem Elliesie (eds.), Legal Transformation in Northern Africa and the South Sudan, The Hague (forthcoming 2013). 
The Abyei Arbitration is widely considered to be a remarkable legal procedure concerning the interpretation and implementation of a peace agreement in which a state's government and a secessionist movement sought the delimitation of an area which could potentially become an inter-state border. Observers assumed that while the parties were unable to enter into new negotiations or to accept a mediated settlement they would be able to respect a decision of an independent, neutral international legal body. Yet, the status of Abyei, i.e. the delimitation and demarcation of its boundaries, and the determination of who is a resident and therefore entitled to vote in a referendum as to whether or not the Abyei Area should join the now independent Republic of South Sudan, are still pending.

Against this background the article gives an overview of the Abyei dispute and the developments that led to the Abyei Arbitration before entering into a discussion on some arguments that were raised by the parties during the arbitration procedure and the Abyei Award delivered by the Tribunal on 22 July 2009. At this example the second part discusses problems, advantages and disadvantages of international arbitration as a mean to settle disputes concerning the interpretation and implementation of peace agreements between state and non-state parties. In a last step it summarises whether and under what conditions international arbitration could serve as framework for dealing with disputes between state and non-state parties to peace agreements in the future.

It inter alia finds that arbitration is an appealing method of dispute settlement, mainly because of its flexibility. At the same time, the parties can expect the procedure to be in accordance with legal principles specified by them. When it comes to the (non-)compliance of the parties, it finds that arbitration can only be effective if the parties genuinely desire a final and legally binding resolution to their (political) dispute, if the tribunal is given an appropriate mandate to address what is at stake between them, and if the implementation of the award is secured by mechanisms, ideally already agreed upon in the arbitration agreement.

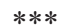

\section{A. Introduction}

A Sudanese proverb says that Abyei would be the 'eye' of the Sudans. It lies in the focus of old tribal conflicts about grazing and land rights: ${ }^{1}$ Two tribes claim their rights over Abyei, the Ngok Dinka, a pastoralist tribe loyal to South Sudan's Sudan People's Liberation Movement/Army (SPLM/A), and the Misseriya, Arab nomads with close ties to the Government

1 "Chief Deng Abot, one of the two deputy Paramount Chiefs of the Ngok Dinka, once said of the Ngok Dinka area at the North-South border that it is like an eye, which is so small but sees so much.", see Francis M. Deng, Frontiers Of Unity. An Experiment in Afro-Arab Cooperation, London \& New York 2009, p. 23. 
of Sudan (GoS), who drive their cattle through this land. ${ }^{2}$ That this Region on the crossroads between Sudan and the now independent Republic of South Sudan (RSS) ${ }^{3}$ additionally turned out to be rich with oil further intensified the disputes about its delimitation and status. ${ }^{4}$ Even after the RSS's independence in 2011 - following the rules and procedures laid out in the 2005 Comprehensive Peace Agreement (CPA) ${ }^{5}$ - the status of Abyei, i.e. the delimitation and demarcation of its boundaries, and the determination of who is a resident and therefore entitled to vote in a referendum as to whether or not the Abyei Area should join the RSS, are still pending. ${ }^{6}$ If at all, these problems were and are addressed by temporary and preliminary agreements and memoranda of understanding that have been broken or simply not implemented. It is too early to say whether The Cooperation Agreement Between the Republic of

2 The complexity of land-claims is reflected in the Abyei Boundary Commission Report, Part I and II, 14 July 2005, available at: http://www.sudantribune.com/TEXT-Abyei-Boundary-Commission,11 633 (last visited 22 March 2013).

3 When South Sudan became independent on 9 July 2012, the United Nations welcomed its independence, and the UN General Assembly admitted the RSS as the $193^{\text {rd }}$ member of the UN on 14 July 2011, see: UN welcomes South Sudan as $193^{\text {rd }}$ Member State, UN News Centre, 14 July 2011, available at: http://www.un.org/apps/news/story.asp?NewsID=39034 (last visited 22 March 2013).

4 In September the parties agreed upon the following definitions: "(1) Border: a region, zone or territory straddling a boundary or an area adjacent to a boundary, (3) Boundary: the line that marks the physical limits of a State's territory and sovereignty, (4) Demarcation: the physical marking of a boundary on the ground using pillars or beacons and production of boundary maps thereafter, (5) Delimitation: the legal description of a boundary in text or maps.", Agreement between the Republic of Sudan and the Republic of South Sudan on Border Issues, 27 September 2012, Part 1, Art. 1, available at: http://ww w.rssnegotiationteam.org/borders.html (last visited 22 March 2013).

5 Under the mediation of the Intergovernmental Authority on Development (IGAD), the Government of the Sudan and the SPLM/A signed a series of six agreements: The Protocol of Machakos (Machakos Protocol), 20 July 2002; The Protocol on Security Arrangements, 25 September 2003; The Protocol on Wealth-Sharing, 7 January 2004; The Protocol on Power-Sharing, 26 May 2004; The Protocol on the Resolution of Conflict in Southern Kordofan/Nuba Mountains and the Blue Nile States, 26 May 2004; and concerning Abyei The Agreement between the Government of Sudan (GoS) and the Sudan People's Liberation Movement/Army (SPLM/A) on the Resolution of the Abyei Conflict, 26 May 2004 (in forth referred to as Abyei Protocol); Understanding of Abyei Boundaries Commission, 17 December 2004 (in forth referred to as Abyei Appendix), for an overview see: http://unmis.unmissio ns.org/Default.aspx?tabid=515 (last visited 22 March 2013).

6 Next to this, the referendum on South Sudan's status was a key-point of the power-sharing arrangement between the GoS and the SPLM/A as laid out in the CPA. The referendum to determine the status of Southern Sudan was held on schedule on 9 January 2011 and with an overwhelming majority of $98.83 \%$ of South Sudan's population voting for independence, while a referendum for Abyei is still pending, for an overview see: http://www.un.org/en/peacekeeping/missions/unmis/background.shtml (last visited 22 March 2013); Sudan: Peace Partners Postpone Addis Ababa Meeting On Abyei Referendum, allAfrica.com, 25 October 2010, available at: http://allafrica.com/stories/201010260503.html (last visited 22 March 2013); The Abyei Referendum, Carnegie Endowment, 4 January 2011, available at: http://sudan.carnegieendowment.org/2011/01/04/the-abyei-referendum (last visited 22 March 2013); International Peace Institute, The Future of South Sudan, May 2011, available at: http://www.ipacad emy.org/index.php (last visited 22 March 2013). 
Sudan and the Republic of South Sudan of 27 September 2012 will be successfully implemented and lead to a sustainable medium and long-term solution. ${ }^{7}$

By including the Abyei Protocol and the Abyei Appendix in its framework, and by establishing the Abyei Boundary Commission (ABC), the parties to the CPA made an attempt to finally solve the pending delimitation and demarcation of the territory back in $2005 .{ }^{8}$ The $\mathrm{ABC}$, however, was not able to produce a final report that would lead to a final settlement. ${ }^{9}$ The Government of Sudan (GoS) accused the ABC of having exceeded its mandate in its fact finding and decision making process and therewith did not accept the results of the ABC's Report. This Report, however, was actually supposed to be final and binding for the CPA's parties. Moreover, the CPA and its Annexes, which had obtained constitutional status in the meantime, did not provide for a dispute settlement mechanism in case the parties did not agree with or failed to follow the ABC's Report. To solve the dispute between the GoS and the SPLM/A concerning the ABC's findings without risking the entire peace process, the parties ultimately decided to seek for an arbitral award to settle the issue. The parties agreed upon an international arbitral tribunal under the umbrella of the Permanent Court for Arbitration (PCA). ${ }^{10}$ This was widely considered to be an unusual and remarkable step of two parties to a peace agreement of which only one was a state. ${ }^{11}$

7 For a detailed documentation of attempts and proposals of the RSS to finally regulate the status of Abyei, see for instance: Republic of South Sudan Negotiation Team: http://www.rssnegotiationtea m.org/past-agreements.html (last visited 22 March 2013); see also U.N.-Doc. S/RES/2046, 2 May 2012; U.N.-Doc. S/RES/2047, 17 May 2012; U.N.-Doc. S/RES/2057, 5 July 2012; U.N.-Doc. S/ RES/2075, 16 November 2012, esp. referring to the 27 September Agreements on Cooperation and Security Arrangements reached by the Government of Sudan and the Government of South Sudan in Addis Ababa under the auspices of the African Union High-Level Implementation Panel; see also African Union High Level Implementation Panel on Sudan: Proposal on the Final Status of Abyei, 21 September 2012, available at: http://www.rssnegotiationteam.org/au-abyei-proposal.htm(llast visited 22 March 2013).

8 See note 5 .

9 See Abyei Boundary Commission Report, note 2.

10 Arbitration Agreement between the Government of Sudan and the Sudan People's Liberation Movement/Army on Delimiting Abyei Area, 7 July 2008, available at: http://www.pca-cpa.org/showpage .asp?pag_id=1306 (last visited 22 March 2013).

11 Soon after the Abyei Award, the literature began addressing questions such as why the parties chose arbitration in the first place and whether this model was a success and could be successfully applied to other disputes, see for example: Freya Baetens / Rumiana Yotova, The Abyei Arbitration: A Model Procedure for Intra-State Dispute Settlement in Resource-Rich Conflict Areas?, Goettingen Journal of International Law 3 (2011), pp. 417-446; Daly Brooks, The Abyei Arbitration: Procedural Aspects of an Intra-state Border Arbitration, Leiden Journal of International Law 23 (2010), pp. 801-823; Wendy J. Miles / Daisy Mallett, The Abyei Arbitration and the Use of Arbitration to Resolve InterState and Intra-State Conflicts, Journal of International Dispute Settlement 1 (2010), pp. 313-340; John R. Crook, Abyei Arbitration - Final Award, ASIL Insight 13 (2009), available at: http://www. asil.org/insights090916.cfm (last visited 22 March 2013); Luisa Vierucci, International arbitrators as part of a peace process: lessons from the Abyei arbitration?, in: D. Alland / V. Chetail / O. de Frouville / J. E. Vinuales (eds.), Unity and Diversity of International Law. Essays in Honour of Professor 
The 2008/2009 Abyei Arbitration raises the following questions concerning the relation between peace agreements between state and non-state parties and international arbitration: (1) which questions were referred to the Tribunal and with that, which mandate was granted by the parties? (2) What was the applicable law defined by the parties? (3) Could the Abyei Arbitration serve as a role model and lesson learned for effective dispute settlement in the course of the implementation of peace agreements between state and non-state parties in the future? To address these questions, the first part will give an overview of the Abyei dispute and the post CPA-developments that led to the Abyei Arbitration before entering into a discussion on arguments that were raised by the parties during the arbitration procedure and the Abyei Award delivered by the Tribunal in July 2009. Taking the example of the Abyei Arbitration, the second part will then discuss advantages and disadvantages of international arbitration as a mean to settle disputes concerning the interpretation and implementation of peace agreements between state and non-state parties.

The last part will summarise and give an outlook whether and under which conditions international arbitration could serve as framework for dealing with disputes between state and non-state parties to peace agreements in the future.

\section{B. The Abyei Area - A Disputed Territory}

Sudan, like most states in the region, had its boundaries constructed by colonial powers that often ignored the routes and settlements of tribal and ethnic groups. This lack of recognition contributed decisively to inter-communal, inter-state, intra-state and regional disputes and affected immediate transboundary inter-tribal interests. ${ }^{12}$

Following the end of the Anglo-Egyptian Condominium, Sudan descended into civil war. Since 1956 one of the major conflict-lines has been between Sudan and South Sudan. The 1972 Addis Ababa Agreement ended the first Sudanese Civil War (1956-1972). ${ }^{13}$ This peace agreement created only a temporary peace. Especially the discovery of oil fuelled the contin-

Pierre-Marie Dupuy / Unité et diversité du droit international. Mélanges en l'honneur du professeur Pierre-Marie Dupuy, Leiden (forthcoming 2013).

12 For a detailed overview see Sara Pantuliano, Oil, land and conflict: The decline of Misseriya pastoralism in Sudan, Review of African Political Economy 37 (2010), p. 7; Douglas H. Johnson, Why Abyei Matters: The Breaking Point of Sudan's Comprehensive Peace Agreement?, African Affairs 107 (2008), pp. 1 et seq.; see also International Crisis Group (ICG), Sudan: Regional Perspectives on the Prospect of Southern Independence, Africa Report Number 159, 6 May 2010; ICG, Sudan: Defining the North-South Border, Africa Briefing Number 75, 2 September 2010; ICG, Negotiating Sudan's North-South Future, Africa Briefing Number 76, 23 November 2010.

13 Addis Ababa Agreement, 27 February 1972, available at: http://peacemaker.un.org/node/1257 (last visited 22 March 2013). 
uous disputes between the sides about territory, and their ambition to have the oil-rich and transit areas, amongst them Abyei, under their control. ${ }^{14}$

The conflict lines between the GoS and the secessionist SPLM/A also influenced rival tribes in the Area. The Ngok Dinka usually supported the rebels and later rose to leadership positions in the ranks of the SPLM/A. The Misseriya, in contrast, opted to side with the central government in Khartoum in the course of the $1980 \mathrm{~s}$. In the end, a referendum about the status of Abyei, as agreed upon on in the Addis Ababa Agreement, was never held. ${ }^{15}$ Then, in 1983, renewed conflicts about power, land rights, natural resources, and self-determination led to the second Sudanese civil war that lasted for two decades. ${ }^{16}$

\section{Abyei and the Comprehensive Peace Agreement}

After over a decade of negotiations facilitated by the Inter-Governmental Authority on Development (IGAD), an East African regional organisation, as well as representatives from the United States of America (USA), the United Kingdom (UK) and Norway, the GoS, mainly composed of the National Congress Party (NCP), and the SPLM/A signed the CPA on 9 January 2005. ${ }^{17}$ The CPA granted substantial competencies to the South, inter alia through

14 For an overview about the interconnectedness between the discovery of oil fields and the Abyei dispute, see Baetens / Yotova, note 11, pp. 421-422; Luke A. Patey, Crude Days Ahead? Oil and The Resource Curse in Sudan, African Affairs 109 (2010), pp. 617-63; Markus Böckenförde, The Abyei Award: Fitting a Diplomatic Square Peg into a Legal Round Hole, Leiden Journal of International Law 23 (2010), p. 557 et seq.; ICG Reports, see note 12.

15 The Addis Ababa Agreement included a clause that provided for a referendum allowing the population of Abyei to choose between either remaining part of Sudan or joining the autonomous South (Art. 2). It furthermore provided South Sudan with regional autonomy and a degree of self-governance (Art. 1). The Addis Ababa Agreement also served as reference for later proposals for the formulation of the Abyei Protocol as part of the CPA, see Addis Ababa Agreement, note 13.

16 By the conclusion of the major fights, reports put the total number of people who died in both wars at over 2 million; over 4.5 million people were internally displaced. Even during the peace process the death toll in South Sudan already topped 1,800 in mid-2011, and more than 260,000 people were displaced, which included about 100,000 people who fled the disputed Abyei Area, see: http://www .reuters.com/article/2011/07/01/us-sudan-violence-idUSTRE7601QM20110701 (last visited 22 March 2013).

17 The CPA consisted of a series of agreements setting out the terms for finally resolving the war between the $\mathrm{GoS}(\mathrm{NCP})$ and the SPLM/A and is an illustrative example of an internationalised comprehensive peace agreement that contains elements that aim to reshape fundamental constitutional aspects of the entire state. The CPA included provisions relating to the governance of the country, in particular political power-sharing, wealth-sharing (involving issues of land ownership and national resource and revenue management), security (including an internationally monitored ceasefire and control over state police forces) and the resolution of the status of the conflict areas of Abyei, Kordofan and Southern Blue Nile - also known as the Three Areas, see note 5, p. 315; Sarah Nouwen, Sudan's Divided (and divisive?) Peace Agreements, Hague Yearbook for International Law 19 (2007), pp. 113-134; concerning the important role of the IGAD mediator Lazaro Sumbeiywo, see Harriet Martin (ed.), Kings of Peace, Pawns of War: The untold story of peace-making, New York 2006, pp. 131-158; concerning the effective asymmetry between the parties during the negotiations and the 
participation in the central government, the establishment of an autonomous Government of South Sudan and oil-revenue sharing arrangements. ${ }^{18}$ The parties also outlined constitutional regulations combining domestic and international law that were designed to make a unified Sudan attractive for the population and former fighters of South Sudan. ${ }^{19}$ Then, after a transitional period of six years, South Sudan was entitled to exercise the right to self-determination in form of a referendum. ${ }^{20}$ With the CPA and the Abyei Protocol and Appendix, the parties also reached the arrangement that in the event that the South exercised its right to self-determination via a referendum, also the residents of Abyei would decide via a referendum whether the Area would remain a part of Sudan or join South Sudan. ${ }^{21}$ To enable such a referendum, the CPA called for the precise delimitation and demarcation of all area-borders, as they existed on 1 January 1956, the day of Sudan's independence. ${ }^{22}$ Establishing the exact line was considered important, not only to finally confirm the respective territories of Sudan and South Sudan, but also for implementing other aspects of the peace agreement, such as the population census, the voter registration and the redeployment of GoS' army (the Sudan Armed Forces, SAF) and the SPLM/A. ${ }^{23}$ The Abyei Protocol specifically outlined the Region's special administrative status governed by a local executive council, the sharing of local oil revenues, and the guarantee of continued access to traditional grazing areas for the two main tribes, the Ngok Dinka and the Misseriya. ${ }^{24}$ Unlike the protocols for Blue Nile and the Nuba Mountains, the Abyei Protocol left the exact boundaries of the territory to be administered undefined. Also unlike the protocols on the status of the other two areas, the final text of the Abyei Protocol was not drafted by the two parties, but in fact presented to them by the US Special Envoy, Senator and Reverend Jack Danforth, to break the impasse in negotiations. ${ }^{25}$ Due to

role pro bono support by international firms played for the SPLM/A, see Maya Steinitz, Internationalized Pro Bono and a New Global Role for Lawyers in the $21^{\text {st }}$ Century: Lessons from NationBuilding in Southern Sudan, Yale Human Rights \& Development Law Journal 12 (2009), pp. 205-240.

18 The Comprehensive Peace Agreement between the Government of the Republic of Sudan and the Sudan People's Liberation Movement/Sudan's People Liberation Army, note 5, Chapter II, III, IV, $\mathrm{V}, \mathrm{VI}$.

19 On current constitutional design in South Sudan, see for example the Center for Constitutional Democracy, Maurer School of Law, Indiana University, http://ccd.indiana.edu (last visited $22 \mathrm{March}$ 2013).

20 The Comprehensive Peace Agreement between the Government of the Republic of Sudan and the Sudan People's Liberation Movement/Sudan's People Liberation Army, note 5, Chapter IV.

21 Abyei Protocol, note 5, Art. 8.

22 The Comprehensive Peace Agreement between the Government of the Republic of Sudan and the Sudan People's Liberation Movement/Sudan's People Liberation Army, note 5, Chapter I, Art. 1.

23 ICG: Sudan: Defining the North-South Border, ICG Policy Briefing, 2 September 2010, p. 2.

24 Abyei, Protocol, note 5, Art. 1.1, 3; on the long way it took to (pre-)negotiate the status of the Abyei Area, see Johnson, note 12, p. 8.

25 GOS-SPLM/A Final Award, 22 July 2009, p. 90, para. 263, available at: http://www.pca-cpa.org/sh owpage.asp?pag_id=1306 (last visited 22 March 2013); Böckenförde, note 14, p. 558; concerning the critical role of religion, and religious motivations in the process see Martin, note 17, pp. 131-158. 
the fact that the parties to the CPA were unable to come to a mutual agreement on the delimitation and demarcation of the Abyei Area, the Abyei Protocol provided for the establishment of the ABC. The task its 15 members was "[...] to define and demarcate the Area of the nine Ngok Dinka Chiefdoms transferred to Kordofan in 1905, referred to as Abyei Area". ${ }^{26}$ These 15 experts, of whom only one had a strong background in law, took testimony from the peoples of the Area and their neighbours, as well as from the two sides, consulted the British Archives, and other relevant sources on Sudan's history to arrive at a decision based on scientific analysis and research. The resulting findings were to be presented in form of a report and were supposed to have a legally binding effect. ${ }^{27}$ Thus, the final decision about the borders of the Abyei Area was left to these 15 experts. ${ }^{28}$ Both, the GoS and the SPLM/A undertook to accept these findings as binding when signing the CPA.

\section{The Abyei Boundary Commissions's Report of 2005}

The ABC presented its Report on 14 July 2005, determining that the Ngok "[...] have a legitimate dominant claim to the territory from the Kordofan-Bahr el-Ghazal boundary north to latitude $10^{\circ} 10^{\prime} \mathrm{N}$ stretching from the boundary with Darfur to the boundary with Upper Nil, as they were in 1956 [...]", while recognising that the two parties had shared rights to the remaining area. ${ }^{29}$ This led the $\mathrm{ABC}$ Experts to decide that it was reasonable and equitable to divide the borderland, Goz, between the Ngok Dinka and the Misseriya, leaving the precise

26 The Comprehensive Peace Agreement between the Government of the Republic of Sudan and the Sudan People's Liberation Movement/Sudan's People Liberation Army, note 5, Chapter IV; Abyei Protocol, note 5, Art. 5; Abyei Appendix, note 5, Art. 1; see also Miles / Mallett, note 11, p. 316; and Baetens / Yotova, note 11, pp. 423 et seq.

27 The $\mathrm{ABC}$ consisted of 15 members, the members were nominated as follows: "Pursuant to Article 5.2 of the Protocol on Abyei, the ABC shall be composed as follows: / 2.1 One representative from each Party; / 2.2 The Parties shall ask the US, UK and the IGAD to nominate five impartial experts knowledgeable in history, geography and any other relevant expertise. The $\mathrm{ABC}$ shall be chaired by one of those experts; / 2.3 Each Party shall nominate two from the present two administrations of Abyei Area; / 2.4 The GOS shall nominate two from the Misseriya; / 2.5 The SPLM/A shall nominate two from the neighbouring Dinka tribes to the South of Abyei Area", see Abyei Appendix, note 5, Art. 2; see also Böckenförde, note 14, p. 559.

28 The ABC convened in Nairobi in April 2005 and heard the presentations of the SPLM/A and GoS delegations. Already then the two sides offered strongly contrasting positions concerning the delimitation and demarcation of the area and the mandate of the ABC, see Johnson, note 12, pp. 10 et seq. Afterwards the $\mathrm{ABC}$ spent six days in the field hearing testimony from the Misseriya and Ngok Dinka before consulting documents in government offices in Khartoum and later in archives in the Universities of Oxford and Durham in the UK. As the documentary records were incomplete it remained for the experts to determine the area covered by the nine Ngok Dinka chiefdoms in 1905, and this proved difficult. The experts resolved this problem by examining the administrative practice of the Condominium, thus colonial practice, and the legal issues surrounding shared resource use, see Abyei Boundary Commission Report, note 2, p. 9 et seq.; see also summary in GOS-SPLM/A Final Award, note 25 , pp. 41 et seq., paras. 122 et seq.

29 Abyei Boundary Commission Report, note 2, p. 21; Baetens / Yotova, note 11, p. 424. 
identification and demarcation of the northern and eastern boundaries of Abyei to a team of professional surveyors. ${ }^{30}$ While the SPLM/A sought immediate implementation of the Report, the GoS asserted that the $\mathrm{ABC}$ had exceeded its mandate and that the Report should not be implemented. However, the CPA had characterised the ABC's findings as final and binding, and it did not outline mechanisms through which the GoS could have appealed against the Report. ${ }^{31}$ In this sensitive situation, the parties could have decided to take their dispute to a domestic (constitutional) court, as the ABC's mandate was based on the CPA (i.e. the Abyei Protocol and Annex), which had acquired constitutional status as the Interim National Constitution (INC) in 2006. ${ }^{32}$

Why and how could this constitutionalisation have been relevant for the settlement of the Abyei dispute? - To begin with, as a peace agreement between a state and a non-state party, the legal status of the CPA would have been permanently in the twilight between international and domestic law as well as between a binding agreement and a political pledge. Without clear regulations concerning the agreement's legal status the two parties could have agreed to modify their agreement or terminate its implementation whenever and however they wanted or even unilaterally decided to do so. The INC, however, could only be amended in accordance with constitutionally prescribed procedures, at least formally. Additionally, violations of the INC would no longer be considered only as violations of the rights of the other party to the agreement but as a violation of Sudan's interim constitution. Though, despite the important change of the CPA's status the two signatories seem to have consistently ignored the legal consequences of constitutionalising the CPA. This became especially visible in their implementation of the Abyei Protocol and their decision to submit their dispute concerning the ABC's Report to the PCA. ${ }^{33}$ All in all, from a general perspective, this form of post-conflict constitution-making raises concerns about the legitimacy of this process conducted between the former conflict-parties, in particular whether it could be able to create accepted, appropriate, effective and neutral domestic monitoring and adjudication mechanisms. ${ }^{34}$ The parties' following decision to seek for an international arbitral award to settle their dispute concerning

30 Taking the results of the ABC Report it became also more and more apparent that it would be necessary to re-negotiate the revenue-sharing in the case that the referendum in South Sudan and a subsequent referendum in Abyei would lead to independence of South Sudan together with Abyei; Abyei Boundary Commission Report, note 2, pp. 21 et seq.; Johnson, note 12, p. 14; for an illustration of the oil sector's development in the last 20 years, see Patey, note 14, pp. 617-636.

31 Abyei Appendix, note 5, Art. 5; Böckenförde, note 14, p. 561.

32 In 2006 the CPA was transformed into the Interim National Constitution (INC) and the dispute concerning the $\mathrm{ABC}$ Report could have settled within the institutions outlined by the INC, Böckenförde, note 14, p. 561.

33 Interim National Constitution of the Republic of the Sudan (INC), adopted by the National Assembly on 6 July 2005 and entered into force on 9 July 2005, available at: http://www.unhcr.org/refworld/d ocid/4ba 749762.html (last visited 22 March 2013); more on the legal dimension of constitutionalising the CPA, see Böckenförde, note 14, pp. 560 et seq.

34 See Böckenförde, note 14, p. 563 and Nouwen, note 17, pp. 2 et seq. 
the findings of the $2005 \mathrm{ABC}$ Report instead of taking the dispute to a domestic or to the constitutional court underlines this concern. ${ }^{35}$

\section{The Road Map and Arbitration Agreement of 2008}

To avoid a backlash to civil war and the failure of the CPA, and after external mediation and negotiation attempts failed, the Sudanese President, Omar al-Bashir, and the President of the autonomous Government of Southern Sudan, Salva Kiir Mayardit, agreed in June 2008 upon The Road Map for Return of IDPs and Implementation of Abyei Protocol. This Road Map provided, among other matters, for the referral of the Abyei dispute to international arbitration. ${ }^{36}$ Having agreed upon international arbitration as a dispute settlement mechanism, it was necessary to determine which legal entities would be parties to the arbitration agreement and under which legal regime the procedure would take place. The parties to the Road Map were the representatives of the GoS (NCP) and the SPLM/A, as the two parties of the CPA and its Annexes. ${ }^{37}$ The GoS and SPLM/A agreed that the threshold issue in the Abyei Arbitration was whether or not the $\mathrm{ABC}$ had exceeded its mandate as conferred under the CPA and the Abyei Protocol, and Annex. ${ }^{38}$

The parties opted for the PCA in The Hague to administer the arbitration proceedings instead of an ad hoc procedure. ${ }^{39}$ The Arbitration Agreement between the GoS and SPLM/A was concluded under a modified form of the PCA Optional Rules for Arbitrating Disputes

35 Concerning possible domestic dispute settlement options in accordance with the INC, see Böckenförde, note 14, p. 561; about the the SPLM/A's resistance to take the dispute to the constitutional court which it assumed to be heavily GoS/NCP-oriented, see Miles / Mallett, note 11, pp. 316 et seq.

36 The Road Map for Return of IDPs and Implementation of Abyei Protocol, 8 June 2008, Art. 4; welcomed by U.N.-Doc. S/PRST/2008/24, 24 June 2008; Baetens / Yotova, note 11, pp. 425 et seq.; Böckenförde, note 14, p.561; Brooks, note 11, pp. 802-803.

37 Concerning the tension between the parties' decision to transfer the dispute between them to an international arbitral tribunal and the constitutional status of the CPA and the Abyei Protocol, see Böckenförde, note 14, p. 563; for a detailed discussion of the rules of procedure of the arbitration procedure and the status of the parties under these rules, see Brooks, note 11, pp. 801 et seq., 822 et seq.

38 Naming the GoS and the SPLM/A as parties of the Arbitration Agreement also ensured that the entities bound by the Award would have at least potentially the effective power to guarantee its implement and enforcement, see Miles / Mallett, note 11, pp. 334 et seq.

39 The parties chose the PCA for a number of reasons. First, the PCA is an internationally recognised institution with a reputation for, and experience in the resolution of border disputes and conflicts involving state and non-state parties. Second, the parties were confident that the PCA would administer the proceedings efficiently and they assumed that the PCA's reputation would enhance the credibility, authority and in the end the legitimacy of the arbitral proceedings and the final award, see Miles / Mallett, note 11, p. 315; Baetens / Yotova, note 11, pp. 419 et seq., 440, 445, see also Brooks, note 11, pp. 802, 822-823 (relation between transparency of the procedure and its perceived legitimacy). 
Between Two Parties of Which Only One is a State. ${ }^{40}$ Thus, the parties had the opportunity to tailor their arbitration agreement to their particular circumstances and to their need for a speedy settlement of the dispute. ${ }^{41}$ With their Arbitration Agreement both parties to the dispute formally committed to abide by and implement the resulting arbitral award. ${ }^{42}$ In accordance with Article 2 of the Arbitration Agreement, the mandate of the Tribunal was to determine:

(a) Whether or not the ABC Experts had, on the basis of the agreement of the Parties as per the CPA, exceeded their mandate which is 'to define (i.e. delimit) and demarcate the area of the nine Ngok Dinka chiefdoms transferred to Kordofan in 1905' as stated in the Abyei Protocol, and reiterated in the Abyei Appendix and the ABC Terms of Reference and Rules of Procedure.

(b) If the Tribunal determines, pursuant to Sub-article (a) herein, that the ABC Experts did not exceed their mandate, it shall make a declaration to that effect and issue an award for the full and immediate implementation of the ABC Report.

(c) If the Tribunal determines, pursuant to Sub-article (a) herein, that the ABC Experts exceeded their mandate, it shall make a declaration to that effect, and shall proceed to define (i.e. delimit) on map the boundaries of the area of the nine Ngok Dinka chiefdoms transferred to Kordofan in 1905, based on the submissions of the Parties. ${ }^{43}$

Additionally, the Tribunal ${ }^{44}$ was required to make its determination in accordance with the applicable law, which was set out in Article 3 of the Arbitration Agreement as follows:

1. The Tribunal shall apply and resolve the disputes before it in accordance with the provisions of the CPA, particularly the Abyei Protocol and the Abyei Appendix, the Interim National Constitution of the Republic of Sudan, 2005, and general principles of law and practices as the Tribunal may determine to be relevant.

2. This Agreement, which consolidates the Abyei Road Map signed on June 8th 2008 and the Memorandum of Understanding signed on June 21 st 2008 by the Parties with the view

40 Arbitration Agreement between the Government of Sudan and the Sudan People's Liberation Movement/Army on Delimiting Abyei Area, note 10, Art. 1.1.; see Brooks, note 11, pp. 801 et seq., 822 et seq.

41 The Arbitration Agreement required the Tribunal to deliver a 'final and binding' Award setting out its reasons within six months of appointment, subject to a maximum three-month extension, see Arbitration Agreement between the Government of Sudan and the Sudan People's Liberation Movement/Army on Delimiting Abyei Area, note 10, Art. 9.1.; for further details see Baetens / Yotova, note 11, pp. 427, 430, 433; and Brooks, note 11, pp. 804 et seq.

42 Arbitration Agreement between the Government of Sudan and the Sudan People's Liberation Movement/Army on Delimiting Abyei Area, note 10, Art. 9.

43 Arbitration Agreement between the Government of Sudan and the Sudan People's Liberation Movement/Army on Delimiting Abyei Area, note 10, Art. 2.

44 Concerning the number and selection of the members of the Tribunal, see Brooks, note 11, pp. 810 et seq. 
of referring their dispute to arbitration, shall also be applied by the Tribunal as binding on the Parties. ${ }^{45}$

Thus, the applicable law was to include the CPA and the Annexes referring to the Abyei Region, as well as general principles of (international) law. The applicable law of Article 3 (1) was considered as lex specialis by the Tribunal and interpreted in accordance with the customary law of treaty interpretation as codified by the Vienna Convention on the Law of Treaties (VCLT) like international treaties. ${ }^{46}$ The Tribunal did not address the constitutional status of the CPA but interpreted it according to rules of interpretation of the VCLT, considering the CPA and the INC due to the wording of the Arbitration Agreement as documents of a distinct status. ${ }^{47}$

\section{The Arbitration Procedure and the Award of July 2009}

During the arbitration procedure the SPLM/A claimed that the ABC had to determine the land occupied and used by the Ngok Dinka in 1905 and to delimit the Area based on that determination. This became known as the tribal interpretation. ${ }^{48}$ The GoS stated that the ABC was required to identify the tract of land that was previously located within the province of Bahr-el-Ghazal and was subsequently transferred to the administrative unit of the province of Kordofan in 1905. This point of view became known as the territorial interpretation. ${ }^{49}$ The GoS also made several procedural complaints about the manner in which the $\mathrm{ABC}$ experts had conducted their tasks. It claimed that there had been a breach by the ABC of mandatory criteria arising from its failure to state reasons, that its decision had been made ex aequo et bono, that it applied unspecified principles determining land rights, and that it wrongfully allocated oil resources. ${ }^{50}$ The SPLM/A responded to those complaints, asserting that the ABC

45 Arbitration Agreement between the Government of Sudan and the Sudan People's Liberation Movement/Army on Delimiting Abyei Area, note 10, Art. 3.

46 GOS-SPLM/A Final Award, note 25, p. 140, para. 396, pp. 150 et seq., paras. 419 et seq. (Analysis of the Tribunal); Miles / Mallett, note 11, pp. 319 et seq.; Vierucci, note 11.

47 Criticising the application of the VCLT, and again that the Tribunal did not address a potential lack of constitutional authorisation to delegate the dispute to international arbitration, see Böckenförde, note 14, pp. 563-564.

48 GOS-SPLM/A Final Award, note 25, pp. 61 et seq., paras. 170 et seq. (Summary of the parties' arguments); As Counsel served inter alia the co-author of an article used in this article, Wendy Miles, from Wilmer Cutler Pickering Hale and Dorr LLP, London, United Kingdom, and Paul R. Williams, international lawyer and the co-founder as well as President of the Public International Law \& Policy Group (PILPG), see: http://publicinternationallawandpolicygroup.org/about/board/p aul-r-williams/ (last visited 22 March 2013).

49 GOS-SPLM/A Final Award, note 25, pp. 60 et seq., paras. 168 et seq. (Summary of the parties' arguments); As Counsel and Advocate for the GoS served inter alia Professor James Crawford, Q.C., SC, F.B.A., Whewell Professor of International Law, University of Cambridge, and Professor Alain Pellet, University of Paris Ouest, Nanterre-La Défense.

50 GOS-SPLM/A Final Award, note 25, pp. 67 et seq., paras. 192 et seq. (Summary of the parties' arguments). 
had correctly interpreted its mandate and did not breach any procedural rules or mandatory criteria.$^{51}$ Furthermore, the GoS argued that the standard of review required the Tribunal not to determine whether the $\mathrm{ABC}$ had reasonably interpreted its mandate, but rather whether it had correctly interpreted it. ${ }^{52}$

In keeping with their differing approaches to the interpretation of the ABC's mandate, the parties submitted their diverging views regarding the appropriate delimitation and demarcation of the Area. The SPLM/A put forward evidence to support the boundaries contained in the $\mathrm{ABC}$ Report, while the GoS argued that a much smaller strip of land was the correct area. $^{53}$

Based on this argumentation, the SPLM/A claimed that the ABC Experts did not overstep the commission's mandate. ${ }^{54}$ The GoS on the other side submitted that the ABC Experts had exceeded their mandate, and that the area of the nine Ngok Dinka chiefdoms transferred to Kordofan in 1905 was the area bounded on the north by the Bahr el-Arab and otherwise by the boundaries of Kordofan as they were at the time of independence. ${ }^{55}$

On 22 July 2009, only 90 days after the oral pleadings in April 2009, the Tribunal issued its Final Award, which had the support of four of the five members of the Tribunal. ${ }^{56}$ The Award partially annulled the conclusions of the ABC Report based on the finding that the ABC Experts had exceeded their mandate and did not state sufficient reason for their findings. The Tribunal adopted the general principle of partial annulment, so that only those parts of the $\mathrm{ABC}$ decision found to be an excess of mandate were to be annulled. ${ }^{57}$ Accordingly, the Tribunal reconsidered the delimitation of the eastern, western and northern boundaries of the Abyei Area, reducing the extent of the Area as defined by the ABC Report. The re-delimitation

51 GOS-SPLM/A Final Award, note 25, pp. 70 et seq., paras. 200 et seq. (Summary of the parties' arguments).

52 GOS-SPLM/A Final Award, note 25, p. 172, para. 489 (Analysis of the Tribunal).

53 According to the SPLM/A, decisions of arbitral tribunals - including decision-making bodies such as the $\mathrm{ABC}$ - were to be afforded maximum deference; see Miles / Mallett, note 11, pp. 320 et seq.

54 Alternatively, the SPLM/A asked the Tribunal if it (the tribunal) determined that the ABC Experts exceeded their mandate to make a declaration that the boundaries of the area of the nine Ngok Dinka Chiefdoms transferred to Kordofan in 1905 were the current boundary of Kordofan and Bahr elGhazal to the South extending to $10^{\circ} 35^{\prime} \mathrm{N}$ latitude to the North and the current boundary of Kordofan and Darfur to the west extending to $29^{\circ} 32^{\prime \prime} 15^{\prime}$ E longitude to the East, see The Sudan People's Liberation Movement/Army Rejoinder, PCA No. GOS-SPLM 53,391, 28 February 2009, para. 885, available at: http://www.pca-cpa.org/showpage.asp?pag_id=1306 (last visited 22 March 2013).

55 Government of Sudan Rejoinder, 28 February 2009, Submission (without paragraph), available at: http://www.pca-cpa.org/showpage.asp?pag_id=1306 (last visited 22 March 2013).

56 See Dissenting Opinion of His Excellency Judge Awn Shawkat Al-Khasawneh Member of the International Court of Justice, 22 July 2009, available at: http://www.pca-cpa.org/showpage.asp?pag id $=1306$ (last visited 22 March 2013).

57 GOS-SPLM/A Final Award, note 25, pp. 146 et seq., paras. 140 et seq. (Analysis of the Tribunal). 
of the northern, ${ }^{58}$ eastern and western boundaries was ordered, while the arbitral panel endorsed the Experts' conclusions with respect to the southern boundaries as well as the grazing and other traditional rights. ${ }^{59}$ As a result, the re-defined borders gave control over some oil fields in the disputed Region to the GoS, but not without assigning several oil fields to the South and reaffirming the status of the town of Abyei as the heartland of the Ngok Dinka. ${ }^{60}$

One of the most interesting points of the Award is the Tribunal's assessment of its mandate, which it was granted by the GoS and the SPLM/A. In the tribunal's view, the sequence of Article 2 required the tribunal to conduct a new review of all evidence if, and only if, the ABC Experts were found to have exceeded their mandate. ${ }^{61}$ Furthermore, the Tribunal found that the parties did not expect or authorise it to evaluate the evidence in such a manner as to amount to a re-determination of the correct boundaries of the Abyei Area in 1905. ${ }^{62}$ Based on general principles of law and practices regarding the annulment of arbitral decisions as well as on the object and purpose of the ABC's constitutive instruments, the Tribunal found in a next step that the Abyei Experts were required to clearly and sufficiently explain their decisions and the reasons underlying them. Thus, the ABC Experts would have exceeded their mandate if some or all of their conclusions were not supported by sufficient reason, if the reasoning was incoherent, or if the reasons provided were obviously contradictory or frivolous. ${ }^{63}$ Applying this standard, the Tribunal found that the predominantly tribal interpretation adopted by the ABC was reasonable in light of the historic facts of the 1905 transfer. Nevertheless, the Tribunal added that, since the interpretation made by the $\mathrm{ABC}$ Experts was subject to a reasonableness test rather than a correctness test, its conclusion should not be taken to suggest that the opposite, predominantly territorial interpretation of the GoS was less reasonable, and moreover that the Tribunal was not required or authorised to decide which of the two possible interpre-

58 The Tribunal decided that "In respect of the ABC Experts' decision that ' $[t]$ he Ngok have a legitimate dominant claim to the territory from the Kordofan - Bahr el-Ghazal boundary north to latitude $10^{\circ} 10^{\prime} \mathrm{N}$,' the $\mathrm{ABC}$ Experts did not exceed their mandate. / In respect of the ABC Experts' decision relating to the "shared secondary rights" area between latitude $10^{\circ} 10^{\prime} \mathrm{N}$ and latitude $10^{\circ} 35^{\prime} \mathrm{N}$, the ABC Experts exceeded their mandate. / The northern boundary of the area of the nine Ngok Dinka chiefdoms transferred to Kordofan in 1905 runs along latitude $10^{\circ} 10^{\prime} 00^{\prime \prime} \mathrm{N}$, from longitude $27^{\circ} 50^{\prime} 00^{\prime \prime}$ E to longitude $29^{\circ} 00^{\prime} 00^{\prime \prime}$.", see GOS-SPLM/A Final Award, note 25, p. 267, para. 770 (Decision).

59 See GOS-SPLM/A Final Award, note 25, p. 258, pp. 267 et seq., paras. 745, 770 et seq. (Decision); PCA Press Release, Abyei Arbitration Final Award Rendered, The Hague, 22 July 2009, available at: http://www.pca-cpa.org/showpage.asp?pag_id=1306 (last visited 22 March 2013).

60 Concerning the resource dimension of the Award, see Baetens / Yotova, note 11, p. 426.

61 In these cases, especially the evidence provided by anthropological experts as presented by the parties was a key factor in the tribunal's decision-making. Additionally, it also considered the seasonal grazing patterns of both the Ngok Dinka and the Misseriya Humr, and how their use of land was affected by the seasonal ecology of the region, see GOS-SPLM/A Final Award, note 25, pp. 246 et seq., paras. 714 et seq. (Analysis of the Tribunal); concerning the role of and possible tension between experts's knowledge and legal decision making, see Böckenförde, note 14, pp. 562, 565, 567.

62 GOS-SPLM/A Final Award, note 25, pp. 141 et seq., paras. 398 et seq. (Analysis of the Tribunal).

63 GOS-SPLM/A Final Award, note 25, p. 187, para. 535. 
tations was more correct. ${ }^{64}$ Whether the focus on correctness instead of reasonableness would have changed the Tribunal's overall findings is, of course, only speculative. In the end, while the neutral and objective decision of the $\mathrm{ABC}$ was supposed to be based on scientific analysis and evidence, the PCA's task was to come to a legal decision on the ABC's decision making. The Tribunal pointed out that the parties selected jurists and scholars of international law as arbitrators, and that their selection had clear implication as to which legal standards would be used to assess whether the ABC Experts had exceeded their mandate, and only if this was found to be the case, it was upon the Tribunal to delimit 'on map' the Abyei Area by applying the parties' lex specialis. ${ }^{65}$ Furthermore, the Tribunal also underlined that its findings would not imply that the parties were entitled to disregard other territorial relationships and customs, specifically those between tribes in the Area. Rather, the Tribunal, referring to previous case law, pointed out that the transfer of sovereignty in the context of (international) legal boundary delimitation should not be construed to extinguish traditional rights to the use of land. ${ }^{66}$ The Tribunal emphasized that the CPA (including the Abyei Protocol) underlined the parties' intention to grant special protection to the traditional rights of the people settling within and in the vicinity of the Abyei Area. ${ }^{67}$ Thus, the PCA called indirectly for a flexible management of the boundaries, the free movement of people and goods, and for special arrangements concerning the usage of resources.

In sum, the Abyei Arbitration is an example of the use of international arbitration to resolve a long-standing, seemingly intractable intra-state territorial dispute by referring to postconflict laws created by the state and the non-state party to the dispute, i.e. especially the CPA. This leads to the assumption that arbitration could be a useful, appropriate and timely form of dispute resolution for protracted domestic conflicts between political factions and/or states and peoples. ${ }^{68}$ The negative record of the Award's implementation, however, indicates that the arbitration procedure between the GoS and the SPLM/A did not necessarily reflect the complexity of interests on the ground, inter alia tribal territorial concepts and relationships rooted in traditional ways of life, as for instance pastoralism, as well as alliances created during war-time. ${ }^{69}$ In the end, this nourishes the concern that an innovative and highly transparent dispute settlement procedure does neither automatically lead to effectiveness nor does it substitute other factors like participation and representation of groups immediately affected by

64 GOS-SPLM/A Final Award, note 25, pp. 141 et seq., paras. 398 et seq. (Analysis of the Tribunal); concerning the different standards of review, see Vierucci, note 11.

65 GOS-SPLM/A Final Award, note 25, p. 145, para. 407 (Analysis of the Tribunal).

66 GOS-SPLM/A Final Award, note 25, p. 260, para. 753 (with reference in fn. 1252).

67 GOS-SPLM/A Final Award, note 25, pp. 259 et seq., paras. 748 et seq. (Analysis of the Tribunal).

68 Following the assessment of Miles / Mallett, note 11, pp. 313 et seq.

69 Pantuliano, note 12 , pp. 8 et seq. 
the Award..$^{70}$ One could ask whether the parties really made 'use' of the opportunity to transfer the dispute to an international arbitration Tribunal and whether they indeed gave a mandate that contributed to addressing and effectively and sustainably settling the conflict by legal means. For some observers it is clear that the award was a political and diplomatic solution which was achieved at the expense of legal coherence and clarity. ${ }^{71}$ Judge Awn Shawkat Al-Khasawneh found in his dissenting opinion concerning the tension between finding a political compromise and solution, and making a legal decision at the same time:

"I am saddened that in this arbitration, which provided a perfect and rare chance for the Tribunal to contribute to the process of peace and reconciliation in Abyei and in the Sudan, that chance has been missed because of a wish to marry an ill-advised, misconceived compromise to a self-imposed restrictive interpretation of its mandate, the Tribunal neither maintained the integrity of its reasoning nor contributed to a durable peace. International law and indeed law in general sometimes provide only simple recipes for complex situations where populations and tribes intermingle and where the livelihood of certain groups transcends borders. "72

In the end, a more extended mandate could have provided an opportunity to consider further aspects, i.e. the cultural construction of borders, the dynamics of state borders and borderlands, and their particular mode of signification to the local people and collision with tribal/community perception of territory and borders, and by that to combine elements of dispute settlement and mediation. ${ }^{73}$

\section{$V$. The Abyei Arbitration - A Model for the Settlement of Intra-State Disputes on the Interpretation and Implementation of Peace Agreements?}

Could the Abyei Arbitration serve as a model for future arbitration procedures dealing with intra-state disputes concerning the interpretation and implementation of peace agreements between state and non-state parties? ${ }^{74}$ First of all, asymmetric parties will usually transfer their dispute to an international arbitral tribunal when bilateral negotiations between them as

70 Comment: This also raises the question whether the Abyei Arbitration was indeed a mean to settle the parties' dispute, which also includes the determination of who is affected by the delimitation and demarcation, who is a resident of the Region, and therefore who is eligible to vote during a referendum.

71 Böckenförde, note 14, pp. 556 et seq., 568-569; Vierucci, note 11.

72 Dissenting Opinion of His Excellency Judge Awn Shawkat Al-Khasawneh, note 56, p. 66, para. 202; Böckenförde, note 14, p. 569 (reflecting on Judge Awn Shawkat Al-Khasawneh dissenting opinion).

73 For an anthropological analysis, see Dereje Feyissa, The cultural constitution of state border: the view from Gambella, Journal of East African Studies 4 (2010), p. 328.

74 See similar question in Baetens / Yotova, note 11, pp. 419, 437 (with a focus on resources and selfdetermination); Brooks, note 11, p. 802 (with a focus on procedural aspects and the 'attractiveness' of arbitration to reach a legal settlement of a political conflict); see also Vierucci, note 11 (who asks whether arbitration is a tool capable of contributing to a peace process). 
well as internationalised negotiation and mediation attempts have failed or have no chance of being successful. The parties will also decide upon an internationalised form of dispute settlement when they see no alternative, legitimate and/or effective way to settle the dispute in front of a national or international court. ${ }^{75}$

Dispute resolution by an international tribunal in a situation like the one in the Abyei Region is usually associated with an added value of neutrality, objectivity and authority. The parties have the choice which regime or mechanism they prefer to refer the settlement of the dispute to and which mandate they want to give to a tribunal. ${ }^{76}$ The parties to an arbitration procedure have to respect the arbitration agreement by virtue of the principle pacta sunt servanda, which also means that they are bound to accept and implement the tribunal's award at the end. This is often contested by the inevitable effect that the following arbitration procedure and award will produce 'winners' and 'losers'. ${ }^{77}$ This raises the question how the implementation and enforcement of a decision of an international arbitration tribunal on the interpretation and implementation of a peace settlement between a state and a non-state party could be enabled and guaranteed at the domestic level.

The international enforcement of arbitral awards is addressed in the Convention on the Recognition and Enforcement of Foreign Arbitral Awards of 1958 (New York Convention) ${ }^{78}$ In signing the New York Convention, states agree to enforce foreign arbitral awards made in the territory of a foreign state, although many countries have exercised their right to limit enforcement to only those awards made in the territory of another member state. ${ }^{79}$ Addi-

75 This perception will usually be based on a power-asymmetry between the state and the non-state party and the latter's doubt about the neutrality, effectiveness and legitimacy of domestic laws and courts' adjudication. Furthermore, the International Court of Justice (ICJ) exclusively deals with disputes between states in accordance with Art. 34 (1) ICJ Statute. Just in form of Advisory Opinions as for instance the Advisory Opinion on the Declaration of Independence of Kosovo the ICJ can deal with questions, which also directly affect non-state parties to a territorial dispute. Yet, this is not a dispute settlement procedure but a legal advice, which was formulated based on request by the UN General Assembly.

76 Baetens / Yotova, note 11, p. 440; Krista E. Wiegand / Emilia J. Powell, Past Experience, Quest for the Best Forum, and Peaceful Attempts to Resolve Territorial Disputes, Journal of Conflict Resolution 55 (2011), pp. 34 et seq.; see also Vierucci, note 11.

77 Even though the parties sought to avoid the typical opposition applicant versus respondent constellation, but instead were placed on the same procedural footing, see Baetens / Yotova, note 11, p. 428; furthermore, even flexible dispute settlement mechanisms follow traditional legal methods and approaches to territory, sovereignty, and the delimitation and demarcation of boundaries will be hardly able to avoid winner-loser perceptions because the settlement involves the loss or gain of territory, see Wiegand / Powell, note 76, p. 39; for comments on the territorial fixation of International Law, see Dino Kritsiotis, Public International Law and Its Territorial Imperative, Michigan Journal of International Law 30 (2009), pp. 547-566.

78 Convention on the Recognition and Enforcement of Foreign Arbitral Awards of 1958, available at: http://www.uncitral.org/pdf/english/texts/arbitration/NY-conv/XXII_1_e.pdf(last visited 22 March 2013), the so-called New York Convention entered into force on 7 June 1959 and has currently 146 parties.

79 New York Convention, note 78, Art. 1 (2); see also Miles / Mallett, note 11, pp 335 et seq. 
tionally, numerous states have exercised their right to reserve the applicability of the New York Convention to commercial arbitral awards ${ }^{80}$ Nevertheless, in principle, an award made in the territory of a foreign state with respect to a domestic matter in the state in which it is to be enforced may be enforceable pursuant to the New York Convention. ${ }^{81}$ This, in turn, presupposes that the content of the award is capable of being enforced by domestic courts. The subject matter of an award resulting from an intra-state dispute over territory and/or the implementation and interpretation of a peace agreement between a state and a non-state party is by its very nature unlikely to be enforceable by a domestic court, especially if the parties did not even attempt to settle the conflict in a domestic court in the first place. ${ }^{82}$ In the end, it seems to be the good faith of the parties to comply with an award and to effectively implement it, which is decisive. ${ }^{83}$

The prospects of an effective implementation of an arbitral award could be enhanced by involving international organisations from the outset of a procedure to the enforcement of the final award ${ }^{84}$ However, it could also be raised doubts as to whether, how and when the involvement of international organisations has per se internationalising, legitimising effects and carries accepted authority with it.

80 The New York Convention entitles a state to declare " $[\ldots]$ that it will apply the Convention only to differences arising out of legal relationships, whether contractual or not, which are considered as commercial under the national law of the State making such declaration.", see New York Convention, note 78, Art. 1 (3). It is unlikely that an arbitral award resulting from an intra-state or inter-state conflict would be characterized as an award arising out of commercial-legal relationships, unless the ownership of significant and valuable natural resources is directly and not only indirectly raised as a key-issue; see also Miles / Mallett, note 11, pp 335 et seq.

81 In addition, the New York Convention applies only to foreign arbitral awards in accordance with Art. 1 (1). An arbitral award relating to a dispute between two intra-state parties, rendered in the same state, would not be enforceable in that state's national courts pursuant to the New York Convention, note 78; Miles / Mallett, note 11, pp 335 et seq.

82 Miles / Mallett, note 11, pp. 334 et seq.; additionally also the involvement of Dutch courts were not considered at any point, Brooks, note 11, p. 808 (referring to UNCITRAL).

83 Similar Vierucci, note 11.

84 In the case of Abyei, the UN Security Council called upon the parties to follow the ABC Report and later welcomed the decision to refer the question to arbitration. The Security Council continued to call upon the parties to implement the PCA Award and to peacefully negotiate the delimitation of Abyei. It also determined the Abyei dispute to be a threat to international peace and security and established the United Nations Interim Security Force for Abyei to monitor the situation and to support a peaceful transition of the Abyei Region. But it did not effectively contribute to enforce the implementation of the Award, see U.N.-Doc. S/RES/1812, 30 April 2008; U.N.-Doc. S/RES/1879, 20 May 2009; U.N.-Doc. S/RES/1919, 29 April 2010; U.N.-Doc. S/RES/1990, 27 June 2011; U.N.Doc. S/RES/1997, 11 July 2011; U.N.-Doc.S/RES/2024, 14 December 2011; U.N.-Doc. S/RES/ 2046, 2 May 2012; The parties to intra-state territorial disputes could also follow Art. 82 of the 1907 Convention on the Pacific Settlement of International Disputes, according to which any dispute relating to the interpretation or execution of an award shall, in the absence of an agreement to the contrary, be submitted to the arbitral tribunal that pronounced it, see Hague Convention I - Pacific Settlement of International Disputes: 29 July 1899, 32 Stat. 1779, 1 Bevans 230, 26 Martens Nouveau Recueil (ser. 2) 720, 187 Consol. T.S. 410, entered into force Sept. 4, 1900. 
In the given context, despite the Abyei Award, the delimitation and demarcation of the Abyei Region remains one of the most contentious issues between Sudan and the independent RSS. ${ }^{85}$ The parties still face the challenge of translating the arbitral award, the interim agreements, parts of the CPA and their numerous political pledges into action by establishing a (legal) framework to identify and regulate cross-border arrangements, movement of people, goods, and the exploitation and transit of resources. ${ }^{86}$ The border and the status of the Abyei Area were and are still only temporarily and preliminary regulated, e.g. by the Agreement between the Republic of Sudan and the Republic of South Sudan on the Demarcation of the Boundary from 13 March $2012^{87}$ and The Agreement from 3 August 2012 on oil transit and border security, which constitutes an important but still only partial step towards a solution, paying tribute to international pressure. In July 2012 the RSS tabled a draft Agreement on Friendly Relations and Cooperation (AFRC) between the Republic of South Sudan and The Republic of Sudan. ${ }^{88}$ Interestingly enough, this detailed proposal entailed a comprehensive

85 Most see demarcation on the ground as necessary to guarantee peace between Sudan and the RSS. Some Southerners hope physical markers will help to prevent any future confusion or encroachment. They believe clear markings will also assist the respective governments in providing administrative services and security. Others are not certain that physical demarcation will ever be possible, as a hard barrier would threaten pastoralist livelihoods in both states alike. Thus, the ideal scenario for postreferendum arrangements is one in which the parties and their border constituencies can achieve the softest border possible. This creates great challenges, also when it comes to defining citizenship of the Region. Hence, a solution for defining the Abyei-borders becomes not only drawing a line, but also defining the nature and management of that border and the future relations of communities on both sides. Currently observers and South Sudan tend to prefer a soft-boundary concept backed by a framework for cross-border arrangements and, if necessary, safeguarded by a joint monitoring mechanism, see for instance ICG, Sudan: Defining the North-South Border, ICG Policy Briefing, 2 September 2010, 1, 15 et seq.; Joint Position Paper on Border Security, Post-Referendum Negotiations Security Cluster, 30 May 2011, Art. I.; African Union, Peace and Security Council, $319^{\text {th }}$ Ministerial Meeting, Communiqué, Addis Ababa, PSC/MIN/COMM/3.(CCCXIX), 24 April 2012, also urging the parties to agree upon a final solution of the Abyei dispute, paras. 10,11,12,13, 14 also referring to U.N.-Doc.S/RES/2024, 14 December 2011; U.N.-Doc. S/RES/2046, 2 May 2012; U.N.Doc. S/RES/2047, 17 May 2012; see also African Union High Level Implementation Panel on Sudan: Proposal on the Final Status of Abyei, 21 September 2012, available at: http://www.rssnegotiationt eam.org/au-abyei-proposal.html (last visited 22 March 2013); see also Vierucci, note 11.

86 Legal issues which inter alia need to be addressed and regulated are the status of commuting groups and individuals, how they are to be identified and where, when and for how long they can cross the border, as well as the rights and responsibilities of individuals on both sides of the boundary (including economic activity, grazing fees, social arrangements and taxation). For an attempt to approach the citizenship, settlement and treatment of non-nationals questions, see Framework Agreement on the Status of Nationals of the Other State and Related Matters between the Republic of the Sudan and the Republic of South Sudan, Addis Ababa, 13 March 2012.

87 Agreement between the Republic of Sudan and the Republic of South Sudan on the Demarcation of the Boundary, 13 March 2012; the negotiation, signing and implementation processes are now documented online by the Government of the Republic of South Sudan's negotiation team, see: http:// www.rssnegotiationteam.org/news.html (last visited 22 March 2013).

88 Agreement on Friendly Relations and Cooperation (AFRC) between the Republic of South Sudan and The Republic of Sudan, Addis Ababa, July 2012. 
section on Peaceful Settlement of Disputed and Claimed Areas (Chapter III) with a special provision on Arbitration of outstanding Disputed and Claimed Areas in Art. 3. Additionally, Art. 5 on International Arbitration, and especially Part VI on General Provisions, envision in detail arbitration as a key-means to solve disputes between the parties. ${ }^{89}$ Similar arbitration clauses can be found in the milestone agreement signed on 27 September 2012. The Cooperation Agreement Between the Republic of Sudan and the Republic of South Sudan, ratified by the Parliaments of Sudan and the RSS in October 2012, is supposed to guarantee the peaceful relationship between the two states and the completion of negotiations on the disputed area. ${ }^{90}$ Though, the future relations between Sudan and the RSS remain fragile and the status of Abyei is still disputed. ${ }^{91}$

\section{Conclusion and Outlook}

The Abyei Arbitration shows that arbitration might not be the ideal choice but it seems, one choice available to solve disputes arising during the implementation of peace agreements between state and non-state parties. When it comes to arbitration's potential as a means and key-mechanism to settle disputes concerning the interpretation and implementation of peace agreements between state and non-state parties it seems opportune to focus on a correlation of factors, namely the parties' willingness to enter into an arbitration agreement to settle their dispute by peaceful means, to recognise the authority of the (legal) decision by a neutral third party, and to accept external enforcement powers in case of non-implementation. For future cases, it might be worth developing an implementation strategy for an award already with the

89 Draft Agreement on Friendly Relations and Cooperation (AFRC) between the Republic of South Sudan and The Republic of Sudan, Addis Ababa, 22 July 2012, Part I, Chapter III, Art. 2; Part VI, Chapter III, Art. 5; with comprehensive parts addressing Border Demarcation (Part I, Chapter II), Border Crossings (Part I, Chapter IV), Part IV Abyei (including a Chapter of Security, Temporary Political Arrangements) and with Chapter III on the Final Status of Abyei, foreseeing a referendum based on the Abyei Referendum Act 2009 and the definition of eligible voters (Art. 2), in case the parties fail to agree on a referendum the UN/AU shall draft an agreement on the referendum and commence its implementation immediately (see Art. 2, para. d.).

90 The Agreement inter alia provides that the African Union High-Level Implementation Panel will continue to engage on the issue of Abyei, together with the African Union and the UN Security Council, see The Cooperation Agreement Between the Republic of Sudan and the Republic of South Sudan, 27 September 2012, see especially Art. 4 "Outstanding Negotiations and CPA Committees", available at: http://www.rssnegotiationteam.org/cooperation-framework.html (last visited 22 March 2013); see also Agreement on Security Arrangements Between the Republic of Sudan and the Republic of South Sudan, 27 September 2012, available at: http://www.rssnegotiationteam.org/securit y-arrangements.html\# (last visited 22 March 2013), Art. 3 about a joint tribal mechanism for the resolution of disputes.

91 Prospects for peace in Abyei remain "bleak", says group, Sudan Tribune, 3 March 2013, available at: http://www.sudantribune.com/spip.php?article45713 (last visited 27 March 2013); The Crisis in Abyei, reliefweb, 1 March 2013, available at: http://reliefweb.int/report/sudan/crisis-abyei (last visited 27 March 2013). 
conclusion of arbitration agreement, e.g. by referring sanction and enforcement mechanisms to external actors or bodies. ${ }^{92}$

Undeniably, disputes concerning the interpretation and implementation of peace agreements between state and non-state parties often float in a legal-political transitional grey zone in which traditional domestic dispute settlement mechanisms are usually not an option for at least one of the parties - even if the agreement has constitutional status, as shown at the example of the CPA. In absence of concrete arrangements on mechanisms to deal with such disputes in peace agreements, the parties often return to violent conflict. ${ }^{93}$ Yet, by including arbitration and alternative dispute settlement clauses in peace agreements between state and non-state parties, i.e. clauses that allow or even require disputes regarding the interpretation or implementation of the peace agreement to be transferred to a third-party dispute settlement mechanism, the peaceful resolution of future disputes between the parties could be promoted and ensured. ${ }^{94}$

Altogether, international arbitration seems an appealing method to resolve conflicts between state and non-state parties in the course of the implementation and interpretation of a peace agreement, because of its inherent flexibility to determine a tribunal's mandate and the applicable law, ${ }^{95}$ while the formal uniformity of practice and procedure in international arbitration, especially under the umbrella of the PCA, offers the parties some degree of certainty. On the one hand the parties can expect the procedure to be in accordance with legal

92 See also Baetens / Yotova, note 11, pp. 443 et seq.

93 Miles / Mallett, note 11, p. 334.

94 For example: Ouagadougou Political Agreement, 4 March 2007, U.N.-Doc. S/2007/144, 13 March 2007; Arusha Peace and Reconciliation Agreement for Burundi, 28 August 2000, available at: http:// peacemaker.un.org/node/1207 (last visited 22 March 2013); Global and Inclusive Agreement on Transition in the Democratic Republic of Congo (The Pretoria Agreement), 16 December 2002, available at: http://peacemaker.un.org/drc-agreementontransition2002 (last visited 22 March 2013); The proposal by the Liberation Tigers of Tamil Eelam on behalf of the Tamil people for an agreement to establish an interim self-governing authority for the North-East of the island of Sri Lanka, October 2003, available at: http://www.tamilnet.com/img/publish/2003/11/proposal.pdf (last visited 22 March 2013); This might be also an inspiration to put Chapter VI, UN-Charter and the most common and accepted methods used to settle international disputes peacefully as set out in Art. 33 of the UN Charter back on the agenda in internationalised intra-state post-conflict and peace making settings. These methods range from diplomatic to legal means, such as negotiation, mediation, conciliation, arbitration, judicial settlement, resort to regional agencies or arrangements, and resort to the UN's or other international organisations' dispute settlement procedures. The essential difference between legal and diplomatic means is the degree and impact of third party involvement. Diplomatic means leave the control of the outcome of the settlement primarily to the parties themselves. With the transfer to legal dispute settlement, a third party is granted competencies to determine a settlement. These various methods are not mutually exclusive. Hence the lines between these methods may be blurred, see Art. 33, UN-Charter, see also Carla S. Copeland, The Use of Arbitration to Settle Territorial Disputes, Fordham Law Review 67 (1999), pp. 3102-3103; see also Vierucci, note 11.

95 Following Miles / Mallett, note 11, p. 325. 
principles identified by them as applying to their relationship and disputes. ${ }^{96}$ On the other hand, the parties may even expressly consent to a tribunal's power to make a decision ex aequo et bono. If the parties do not do so, it is incumbent on the tribunal to render a decision that upholds the rule of law in accordance with the applicable law as identified by them. ${ }^{97}$

In the end the Abyei Arbitration Award may not have led to the final settlement of the dispute or to maximum compliance and implementation by the parties, but it constitutes a strong example and lesson learned of the attempt to settle an intra-state territorial dispute based on a peace agreement and its annexes in front of an international tribunal. However, it should be accepted that peaceful and violent attempts to settle disputes are not per se mutually exclusive.

In sum, often-high expectations are connected to the power and effect of law and international legal dispute settlement. Whether one holds these high expectations or not, it can be stated that arbitration could be a useful and effective mechanism for resolving legal disputes with a political and cultural dimension, both in respect to the original conflict itself (for example, by referring a conflict regarding the delimitation of a territorial boundary to arbitration), or as a default mechanism for resolving disputes arising in the course of the implementation or interpretation of a peace agreement. Arbitration can be an effective dispute settlement where the parties to a conflict genuinely desire a final, peaceful and legally binding resolution to their dispute, when the tribunal is given an appropriate mandate to address what is at stake between the parties, and when the implementation of the award is in turn secured by mechanisms, ideally already agreed upon by the parties in their arbitration agreement. The question whether the parties will comply with an award is the other side of the coin; a party cannot be forced or required to engage in an arbitrational process or to comply with the award, as shown above. Despite the principle pacta sunt servanda, which binds the parties to their arbitration agreement and their commitment to accept an arbitral award, the effectiveness of the award depends on the will and good faith of the state and non-state parties to comply with it.

96 Additionally, where appropriate and necessary, the parties are also free to agree on the nomination of arbitrators with specific technical, cultural, legal, political and social backgrounds.

97 Miles / Mallett, note 11, p. 325. 